\title{
Karakteristik Pepton dari Limbah Ikan Kurisi (Nemipterus sp.) sebagai Media Pertumbuhan Bakteri yang Terjamin Halal
}

\section{Characteristics of Peptone from Threadfin Bream (Nemipterus sp.) Waste as a Halal Bacterial Growth Medium}

\author{
Moh. Dwi Pratomo ${ }^{1}$, Dian W. Wardanidan ${ }^{1}$, Nur A. Revonagara ${ }^{1}$, Dinda Ersyah ${ }^{1}$, Dwi \\ Setijawati ${ }^{1,2}$, Hefti Salis Yufidasari ${ }^{1,2}$ dan A. Aziz Jaziri ${ }^{1,2,3^{*}}$ \\ ${ }^{1}$ Program Studi Teknologi Hasil Perikanan, Fakultas Perikanan dan Ilmu Kelautan, Universitas \\ Brawijaya, Jalan Veteran, Malang 65149, Indonesia \\ ${ }^{2}$ Kelompok Kajian Bioseafood, Fakultas Perikanan dan Ilmu Kelautan, Universitas Brawijaya, Jalan \\ Veteran, Malang 65149, Indonesia \\ ${ }^{3}$ Halal Thoyib Science Center, Universitas Brawijaya, Jalan Veteran No 16 Ketawanggede, \\ Lowokwaru Malang 65145, Indonesia
}

*Correspondence :
azizjaziri@ub.ac.id

Received : 2019-11-24

Accepted : 2020-01-02

Kata Kunci :

Jenis asam, Hidrolisis, Limbah kurisi, Mikroba, Pepton

Keywords :

Fish waste, Hydrolysis, Type of acids, Peptone, Bacterial culture

\begin{abstract}
Abstrak
Pepton merupakan sumber nitrogen sebagai media pertumbuhan mikroorganisme. Umumnya, pepton di Indonesia yang berasal dari hewan darat yaitu sapi dan babi serta turunannya masih impor dengan harga yang tinggi. Penggunaan pepton yang berasal dari babi jelas diharamkan, sedangkan dari sapi dikhawatirkan terdapat penyakit BSE (bovine spongiform encephalopathy) dan TSE (transmissible spongiform encephalopathy) yang dapat menular ke manusia. Sebagai alternatif, pepton dari limbah pengolahan ikan yang sudah terjamin halal, salah satunya limbah ikan kurisi (Nemipterus sp.). Tujuan penelitian ini mendapatkan pepton dengan tiga perlakuan asam berbeda (asam sitrat, asam format, dan asam propionat) menggunakan metode eksperimen dengan rancangan acak lengkap (RAL). Hasil penelitian menunjukkan bahwa perlakuan tiga jenis asam berpengaruh nyata terhadap nilai rendemen, total $\mathrm{N}$, protein, protein terlarut, pertumbuhan bakteri Escherichia coli dan Staphylococcus aureus serta biomassanya. Rata-rata tertinggi rendemen basah didapatkan $66,17 \%$ sedangkan rendemen kering $3,87 \%$ pada perlakuan asam format. Nilai $\mathrm{pH}$ tertinggi 5,3 pada asam sitrat. Uji karakteristik pepton limbah ikan kurisi menunjukkan bahwa kandungan protein terlarut berkisar 2-4 g/L, total N 1-1,3 \%, dan total protein 6.8-12\%. Asam amino yang terkandung terdiri dari asam amino esensial dan non-esensial. Nilai optical density dan biomassa bakteri ditumbuhkan pada media yang menggunakan pepton limbah ikan kurisi lebih tinggi dibandingkan pertumbuhan bakteri $E$. coli dan $S$. aureus pada media yang menggunakan pepton komersial. Temuan ini mengungkapkan bahwa pepton dari limbah ikan kurisi fisibel dikembangkan sebagai produk halal secara komersial untuk media pertumbuhan mikroba.
\end{abstract}




\begin{abstract}
Peptone is one of the ingredients needed as a source of nitrogen on the growth of microorganisms. Peptone generally comes from land animals namely pigs and cows, it shows the pigs are obviously banned, in addition cows have health problems such as BSE (bovine spongiform encephalopathy) and TSE (transmissible spongiform encephalopathy). Halal Peptone alternatives derived from the waste of Nemipterus sp. potentially to be explored the value of production and characteristics of peptone as a side result of surimi production. The purpose of this research is to know the results of Peptone production using three different acids (citric acid, formic acid and propionic acid) on the yield value, physicochemical characteristics and analysis of the growth of $E$. coli and $S$. aureus bacteria. The highest average wet yield was $66.17 \%$ while a dry bath was $3.87 \%$ in acid format. The highest $\mathrm{pH}$ value is 5.3 on citric acid. The characteristic of peptone from Nemipterus sp. by product such as soluble protein content ranged $2-4 \mathrm{~g} / \mathrm{L}$, total nitrogen content $1-1.3 \%$, and crude protein content $6.8-12 \%$. Amino acids contained in peptone consist of essential amino acids and non-essential amino acids. Biomass production and growth culture from $E$. coli and $S$. aureus from peptone of Nemipterus sp. waste were higher compared to commercial peptone. The findings revealed that it is feasible for peptone of fish processing by-product as future commercial halal product for microbial culture.
\end{abstract}

\section{PENDAHULUAN}

Salah satu isu utama dan menjadi perhatian masyarakat adalah kehalalan suatu produk. Menurut UU No. 33 Tahun 2014 tentang Jaminan Produk Halal, produk yang beredar di pasaran diantaranya makanan, minuman, obatobatan, kosmetik, produk kimia, biologi dan rekayasa genetik serta peralatan yang digunakan pada proses produksi wajib bersertifikasi halal. Salah satu produk mikrobiologi adalah media pertumbuhan mikroba yaitu pepton.

Pepton merupakan salah satu bahan yang digunakan sebagai sumber nitrogen pada media pertumbuhan mikroba (Saputra dan Nurhayati, 2013). Pepton diekstraksi dengan hidrolisis protein dari bahan pangan. Kebutuhan pepton di Indonesia rata-rata 5 juta $\mathrm{kg}$ per tahun, dengan nilai USD 20 juta. Pepton digunakan di laboratorium dan industri bioteknologi, seperti pangan, farmasi, maupun obat-obatan. Kebutuhan pepton dipenuhi melalui impor dengan harga sangat mahal dan cenderung meningkat setiap tahun (Atma et al., 2018). Namun, isu kehalalan suatu produk menjadi perhatian khusus, salah satunya pada produk mikrobial. Titik kritis produk mikrobial terdapat di media pertumbuhannya sebagaimana yang tertulis pada Halal Assurance System (HAS) Majelis Ulama Indonesia (MUI) dan UU Jaminan Produk Halal (JPH).

Umumnya, sumber utama pepton berasal dari hewan darat, seperti babi, sapi. Babi diharamkan menurut Islam, sementara sapi memiliki masalah seperti bovine spongiform encephalopathy (BSE), dan transmissible spongiform encephalopathy (TSE) (Trivedi et al., 2015) dan beberapa agama tidak membolehkan menggunakan sapi. Oleh karena itu, dibutuhkan pepton dari bahan baku lainnya, yang tidak berisiko penyakit dan jelas kehalalannya, seperti limbah pengolahan hasil perikanan. Limbah perikanan sangat potensial sebagai pepton 
halal, dimana jumlah limbah pengolahan hasil perikanan sebesar 40\%. Produksi perikanan nasional mencapai 23,26 juta ton pada 2017. Apabila dihitung limbahnya didapatkan sebanyak 6,97 juta ton, dan apabila termanfaatkan menjadi pepton maka menghasilkan 24,9 ribu ton, dimana $1 \mathrm{~kg}$ pepton membutuhkan $280 \mathrm{~kg}$ ikan.

Produksi pepton halal secara kimiawi menggunakan pelarut asam, seperti asam format, sitrat, dan propionat (Shirahigue et al., 2018). Pelarut tersebut termasuk halal positive list, melaporkan bahwa pepton dari limbah ikan nila dan cobia dengan kombinasi asam sitrat, propionat dan format mempunyai kesamaan dengan pepton komersial (Shirahigue et al., 2018). Hal ini memberikan peluang pemanfaatan limbah ikan lainnya sebagai sumber pepton halal, salah satunya limbah pengolahan ikan surimi.

Pengolahan surimi umumnya menggunakan ikan kurisi (Nemipterus sp.) sebagai bahan baku utama. Limbah pengolahan surimi dari ikan kurisi salah satunya kepala ikan kurisi yang mencapai $30 \%$ yang tidak banyak dimanfaatkan, bahkan ketersediaannya mampu menyebabkan pencemaran di lingkungan. Oleh karena itu, pemanfaatan limbah surimi menjadi produk yang memiliki nilai jual dan nilai tambah sangat diharapkan, seperti sebagai bahan produksi pepton halal untuk pertumbuhan mikroorganisme. Selain itu, tidak ditemukan penelitian yang mengeksplorasi pemanfaatan limbah surimi dari ikan kurisi sebagai produksi pepton, sehingga penelitian ini untuk memproduksi inovasi media ready to use terjamin halal sebagai sumber nitrogen pada pertumbuhan mikroorganisme dari limbah pengolahan surimi ikan kurisi.

\section{METODOLOGI}

\section{Waktu dan Tempat}

Penelitian ini dilakukan di Universitas Brawijaya.

\section{Materi Penelitian}

Bahan yang digunakan untuk pembuatan pepton halal meliputi limbah kepala ikan kurisi (Nemipterus sp.) yang diperoleh dari PT. Kelola Mina Laut Tuban, asam sitrat, asam format, asam propionat, aluminium foil, kertas label, dan akuades. Adapun bahan yang digunakan untuk analisa meliputi larutan $\mathrm{H}_{2} \mathrm{SO}_{4}$ pekat, $\mathrm{NaOH} 45 \%$, tablet Kjeldahl, $4 \mathrm{M}$ asam metanesulfonat yang mengandung $\quad 0,2 \% \quad(\mathrm{v} / \mathrm{v}) \quad 3-2 \quad(2-$ aminoetil), $3 \mathrm{M} \mathrm{NaOH}, 0,2 \mathrm{M}$ buffer sitrat $(\mathrm{pH} 2,2)$, Alikuot 0,04 $\mathrm{mL}$, pepton komersial (merek Difco), $1 \mathrm{M} \mathrm{HCl}$, dan Yeast extract.

Alat yang digunakan dalam proses pembuatan pepton halal yaitu baskom, blender, coolbox, stopwatch, termometer, oven vakum, hot plate, beaker glass 500 $\mathrm{ml}$, nampan aluminium, spatula, gelas ukur $100 \mathrm{ml}$, timbangan digital, sentrifuge, waterbath, dan spektrofotometer. Alat yang digunakan untuk analisa adalah $\mathrm{pH}$ meter, beaker glass, timbangan analitik, kuvet, oven, cawan porselen, tanur, desikator, dan soxhlet.

\section{Rancangan Penelitian}

Metode yang digunakan adalah metode eksperimen. Metode ini bertujuan untuk mengetahui ada atau tidaknya pengaruh penambahan pelarut asam kualitas produksi pepton halal.

\section{Prosedur Kerja}

Prosedur penelitian produksi pepton halal dari limbah ikan kurisi (Nemipterus sp.) seperti yang dijelaskan oleh Shirahigue et al. (2018) dengan sedikit modifikasi. Tahapan pertama yang dilakukan adalah analisis dan produksi pepton dari limbah surimi kurisi. Limbah kepala ikan kurisi dihaluskan dan diukur $\mathrm{pH}$ awal, kemudian ditambahkan 10\% akuades diikuti dengan penambahan 5\% asam format, propionat dan sitrat pada masing-masing perlakuan. Setelah penambahan asam, dilakukan perlakuan $\mathrm{pH}$ terukur pada nilai $\mathrm{pH}$ 4. Dilakukan pengadukan sampai homogen kemudian 
ditutup menggunakan aluminium foil hingga separuh bagian daripada beaker glass tertutup. Perlakuan selanjutnya yaitu inkubasi pada suhu $40^{\circ} \mathrm{C}$ menggunakan waterbath selama 120 jam (5 hari) dengan pengecekan dilakukan setiap 24 jam sekali dengan cara menggojok larutan pada beaker glass. Selama inkubasi terjadi pembusukan yang merupakan proses hidrolisis yakni perombakan enzim endogen dalam memecah protein menjadi peptida. Setelah masa inkubasi selesai, pindahkan $12 \mathrm{~mL}$ larutan ke dalam kuvet berukuran $15 \mathrm{~mL}$, kemudian sentrifuge menggunakan kecepatan $5000 \mathrm{rpm}$ selama 20 menit.

Hasil sentrifuge didapatkan 3 fase sampel yaitu solid phase, aquoeous phase dan oil phase. Sampel yang diambil dan dilakukan uji lanjutan adalah aqueous phase, sehingga pengambilan aqueous phase dilakukan menggunakan mikro pipet dan dipindahkan ke dalam tabung vial kaca. Rendemen yang didapatkan diukur $\mathrm{pH}$ akhir menggunakan $\mathrm{pH}$ meter dan dihitung berat rendemen yang didapatkan menggunakan timbangan digital. Setelah didapatkan data rendemen, perlakuan selanjutnya adalah spray dry yang bertujuan untuk mengubah sampel pada fase cair menjadi fase padatan atau bubuk, kemudian dilanjutkan ke tahap kedua.

\section{Rendemen}

Rendemen pepton diperoleh dengan menghitung perbandingan antara berat akhir yang dihasilkan dengan berat awal (limbah ikan kurisi). Besarnya rendemen dapat dihitung menggunakan rumus:

Rendemen $=\frac{\text { Berat akhir }}{\text { Berat awal }} \times 100 \%$

\section{Nilai pH Pepton}

Sebanya $15 \mathrm{~mL}$ sampel dituang ke dalam beaker glass $50 \mathrm{~mL}$ kemudian diukur derajat keasamannya $(\mathrm{pH})$ pada suhu kamar menggunakan alat $\mathrm{pH}$ meter.

\section{Analisis Proksimat}

Tahap kedua yang dilakukan yaitu analisis dan karakterisasi kimiawi pepton halal berupa komposisi proksimat bahan, $\mathrm{N}$ total, total protein dan protein terlarut pepton (AOAC, 2005).

Penentuan kadar air dilakukan dengan metode gravimetri (pengeringan dengan oven). Kadar air dapat ditimbang dengan rumus :

Kadar Air $=\frac{\text { W1-W2 }}{\text { Berat Sampel }} \times 100 \%$
Keterangan :
$\mathrm{W}_{1}=\begin{aligned} & \text { Berat (sampel }+ \text { cawan) } \\ & \text { dikeringkan }\end{aligned}$
$\mathrm{W}_{2}=\begin{aligned} & \text { Berat (sampel } \\ & \text { dikeringkan }\end{aligned}$

Penentuan kadar protein dilakukan dengan metode Kjeldahl. Perhitungan kadar protein menggunakan rumus :

$\% \mathrm{~N}=\frac{(\mathrm{ml} \mathrm{HCl}-\mathrm{ml} \text { blangko) } \mathrm{x} 14.007 \times \mathrm{N} \mathrm{HCl}}{\mathrm{mg} \mathrm{Sampel}} \times 100 \%$

$\%$ Protein $=\% \mathrm{~N} \times 6,25$

Kadar lemak dapat ditentukan menggunakan metode Soxhlet. Penentuan kadar lemak menggunakan rumus:

Kadar Lemak $=\frac{\text { (berat labu akhir-berat labu awal) }}{\text { Berat Sampel }} \times 100 \%$

\section{Asam Amino}

Komposisi asam amino dari sampel pepton dianalisis sesuai dengan metode Nagarajan et al. (2012) dengan sedikit modifikasi. Sampel dihidrolisis di bawah tekanan yang dikurangi dalam $4 \mathrm{M}$ asam metanesulfonat yang mengandung $0,2 \%$ (v/v) 3-2 (2-aminoetil) indole pada $115^{\circ} \mathrm{C}$ selama 24 jam. Hidrolisat dinetralkan dengan 3,5 $\mathrm{M} \mathrm{NaOH}$ dan diencerkan dengan $0,2 \mathrm{M}$ buffer sitrat $(\mathrm{pH} 2,2)$. Alikuot $0,04 \mathrm{ml}$ diaplikasikan pada penganalisis asam amino (MLC-703; Jepang).

\section{Persiapan Media Kultur}

Media cair untuk kultur mikroba menggunakan dekstrosa $0,1 \%(\mathrm{v} / \mathrm{v})$ dan pepton $0,5 \%(\mathrm{w} / \mathrm{v})$ dalam air destilat. Pepton komersial (Difco, Pittsburgh, PA, 
USA) digunakan sebagai pembanding. $\mathrm{pH}$ dikondisikan 7,0 menggunakan $1 \mathrm{M} \mathrm{HCl}$ atau $1 \mathrm{M} \mathrm{NaOH}$. Media kultur disterilisasi dengan autoklaf pada suhu $121{ }^{\circ} \mathrm{C}$ selama 15 menit (Poernomo dan Buckle, 2002).

Pertumbuhan Escherichia coli dan Staphylococcus aureus juga dapat dikultur pada media Luria Bertani Broth seperti penelitian yang dilakukan oleh Gildberg et al. (2010), komposisi LB Broth yang digunakan yaitu $1 \%(\mathrm{~b} / \mathrm{v}) \mathrm{NaCl}, 0,5 \%$ $(\mathrm{b} / \mathrm{v})$ yeast extract dan $1 \%(\mathrm{~b} / \mathrm{v})$ pepton. Disterilisasi dan hasil kultur diinkubasi pada suhu $37^{\circ} \mathrm{C}$ selama 24 jam.

\section{Deteksi Pertumbuhan Mikroba dari Nilai Optical Density (OD)}

Setelah dilakukan regenerasi bakteri, satu koloni bakteri dimasukkan di dalam larutan steril yang terdiri dari $0,89 \% \mathrm{NaCl}$. Volume larutan $100 \mu \mathrm{L}$ dari setiap suspensi (mengandung 1-2 $\times 10^{8}$ $\mathrm{CFU} \mathrm{mL} \mathrm{m}^{-1}$ ) yang diinokulasi di dalam 100 $\mathrm{mL}$ media cair yang telah disterilisasi. Kultur diinkubasi pada suhu $37^{\circ} \mathrm{C}$ selama 24 jam. Pertumbuhan bakteri diukur pada $600 \mathrm{~nm}$ secara periodik sampai 36 jam.

\section{Biomassa}

Produksi biomassa diukur menurut Poernomo dan Buckle (2002). Sampel 25
$\mathrm{mL}$ pepton (komersial dan uji) dipindahkan ke falcon tube steril dan disentrifugasi 5000 rpm selama 20 menit. Endapan diambil dan ditambahkan $2 \mathrm{ml}$ larutan $\mathrm{NaCl}$ 0,85\% (w/v) kemudian disentrifugasi lagi di $5.000 \mathrm{rpm}$ selama 20 menit. Endapan dipindahkan ke cawan petri untuk merekam berat segar, kemudian dioven pada suhu $105{ }^{\circ} \mathrm{C}$ selama 24 Jam, dan ditimbang untuk mencatat berat kering. Nilainya dinyatakan sebagai biomassa $100 \mathrm{ml} / \mathrm{g}$.

\section{Analisis Data}

Analisis data dilakukan menggunakan one way ANOVA RAL sederhana dengan tiga kali ulangan dan uji Tukey dengan software SPSS 20.0. Setelah data dianalisis kemudian diinterpretasikan untuk menentukan signifikansi setiap perlakukan yang diuji cobakan pada penelitian ini.

\section{HASIL DAN PEMBAHASAN Komposisi Proksimat}

Hasil proksimat bahan baku limbah kepala ikan kurisi (Nemipterus sp.) berupa kadar air, protein dan lemak terdapat pada Tabel 1.

Tabel 1. Hasil proksimat (\%) kepala ikan kurisi.

\begin{tabular}{lc}
\hline Parameter & \% Proksimat \\
\hline Protein & $16,52 \pm 0,22$ \\
Lemak & $0,53 \pm 0,03$ \\
Kadar Air & $79,26 \pm 0,19$ \\
\hline
\end{tabular}

Berdasarkan analisis proksimat limbah ikan kurisi didapatkan kandungan protein sebesar $16,52 \%$, lemak 0,53\%, dan kadar air 79,26\%. Saputra dan Nurhayati (2013) menyatakan bahwa kandungan protein bahan baku pepton ikan lebih tinggi dari pada bahan selain ikan, dan sangat bagus digunakan produksi pepton dikarenakan semakin tinggi proteinnya, maka total nitrogen yang terkandung pada pepton akan semakin tinggi, dimana nitrogen adalah salah satu unsur yang digunakan untuk pertumbuhan mikroorganisme (Najim et al., 2015).

\section{Rendemen}

Rendemen merupakan salah satu parameter yang penting dalam proses pembuatan pepton. Semakin tinggi rendemen yang dihasilkan dalam proses pembuatan pepton menandakan semakin 
efisien perlakuan yang diterapkan serta tingginya kandungan pepton dalam limbah ikan kurisi dengan catatan tidak mengesampingkan sifat fisika maupun kimia yang lainnya. Nilai rendemen basah pepton yang berasal dari limbah kurisi yang diekstrak dengan perlakuan asam berbeda (asam sitrat, asam format dan asam propionat) dan nilai rendemen pepton setelah mengalami pengeringan menggunakan spray dryer dapat dilihat pada Gambar 1.

Hasil analisis ANOVA menunjukkan perbedaan jenis asam menghasilkan perbedaan nyata terhadap rendemen basah dan kering $(p<0,05)$. Hal ini menunjukkan bahwa terdapat pengaruh nyata antara perbedaan asam dengan hasil rendemen yang didapatkan. Persentase rata-rata rendemen basah dan kering tertinggi didapatkan oleh perlakuan asam format dengan nilai $66,17 \%$ dan $3,87 \%$. Hasil tertinggi dari rendemen kering pepton kepala ikan kurisi sebesar 3,87\%. Rendemen yang dihasilkan dalam penelitian ini lebih tinggi jika dibandingkan dengan pepton yang berasal dari ikan selar yaitu 3,54\% (Wijayanti, 2009). Asam format mempunyai kemampuan autolisis pada bahan baku lebih maksimal dan dapat memisahkan fase cair (crude peptone) dengan fase minyak lebih baik dibandingkan kedua asam lainnya (Gildberg et al., 2010).

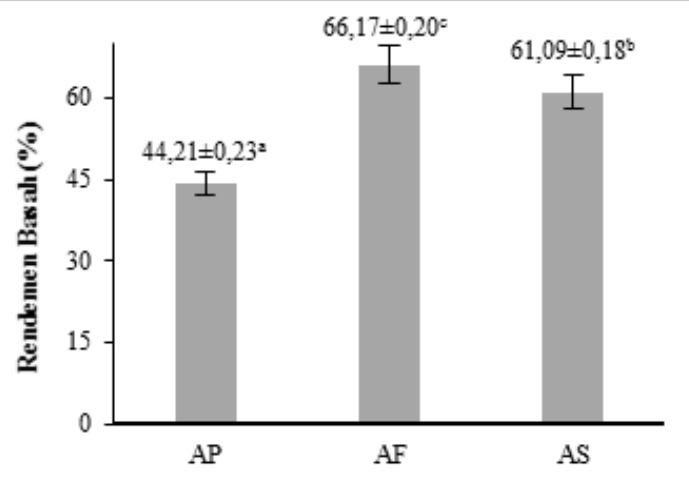

(a)

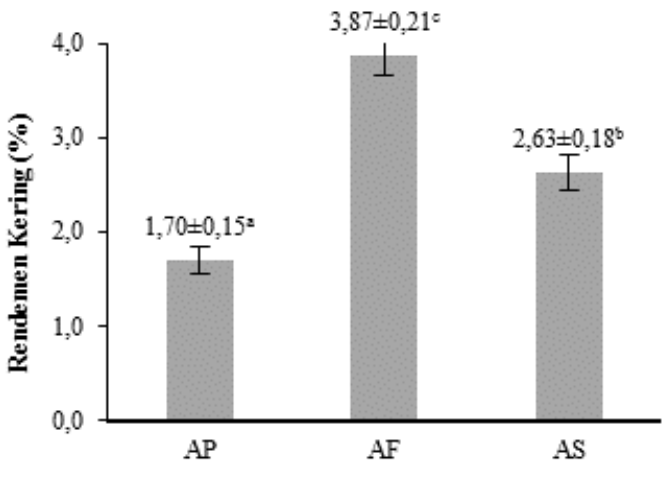

(b)

Gambar 1. (a) Rendemen basah (b) rendemen kering pepton ikan kurisi. AP: asam propionat, AF: asam fosfat, AS: asam sitrat.

\section{Nilai pH}

Derajat keasaman $(\mathrm{pH})$ pada produksi pepton menjadi salah satu parameter penting dalam produksi pepton dari limbah ikan kurisi. Pengukuran nilai
$\mathrm{pH}$ larutan dilakukan untuk mengetahui sifat pepton yang terhidrolisis oleh tiga perlakuan asam berbeda. Nilai rerata $\mathrm{pH}$ pepton dari limbah ikan kurisi dapat dilihat pada Tabel 2.

Tabel 2. Nilai rerata $\mathrm{pH}$.

\begin{tabular}{lccc}
\hline \multicolumn{1}{c}{ Perlakuan } & $\mathrm{pH}$ Awal Sampel & $\mathrm{pH}$ Awal Inkubasi & $\mathrm{pH}$ Akhir Inkubasi \\
\hline Asam Propionat & & 4,1 & 3,6 \\
Asam Format & 6,9 & 4,1 & 4,5 \\
Asam Sitrat & & 4,1 & 5,3 \\
\hline
\end{tabular}

Nilai $\mathrm{pH}$ yang rendah menunjukkan terdenaturasinya protein dalam daging ikan kurisi sehingga mengakibatkan pemecahan ikatan asam amino. Nilai $\mathrm{pH}$ yang didapatkan menunjukkan konsentrasi ion $\mathrm{H}$ - yang dilepas selama masa hidrolisis (Saputra dan Nurhayati, 2013). Hasil penelitian Yin et al. (2008) menyebutkan bahwa selama hidrolisis, kisaran pH berada pada 4,0-6,0 lalu 
mengalami perubahan pada kisaran 3,07,0 .

\section{Total Protein, N Total dan Protein Terlarut}

Nilai total protein, $\mathrm{N}$ total, dan protein terlarut masing-masing perlakuan dapat dilihat pada Tabel 3. Hasil analisis ANOVA menunjukkan perbedaan jenis asam menghasilkan perbedaan nyata terhadap total protein, protein terlarut dan total Nitrogen $(\mathrm{p}<0,05)$. Perlakuan terbaik yang menghasilkan protein terlarut, total protein dan total nitrogen dengan membandingkan pepton komersial dan pepton hasil hidrolisis asam propionat, format, dan sitrat adalah pepton dengan perlakuan asam propionat yang mendapatkan nilai 3,68 g/l, 8,12\% dan $1,30 \%$. Hasil ini menujukan bahwa pepton dari limbah ikan kurisi memiliki nilai total protein dan total nitrogen lebih tinggi daripada pepton komersial yaitu $3,13 \%$ dan $0,50 \%$.

Pepton yang mempunyai kandungan nitrogen yang tinggi merupakan pepton dengan mutu tinggi. Uji total nitrogen merupakan analisis yang dilakukan untuk mengetahui kemampuan pepton dalam memenuhi kebutuhan nitrogen bagi mikroorganisme (Wijayanti, 2009). Semakin tinggi total nitrogen yang didapatkan, maka semakin tinggi nutrisi yang tersedia untuk digunakan pada pertumbuhan mikroba.

Tabel 3. Total protein, $\mathrm{N}$ total, dan protein terlarut.

\begin{tabular}{llll}
\hline Perlakuan & Total Protein & N Total & Protein Terlarut \\
\hline Asam Propionat & $8,12 \pm 0,05^{\mathrm{c}}$ & $1,3 \pm 0,01^{\mathrm{c}}$ & $3,69 \pm 0,06^{\mathrm{c}}$ \\
Asam Format & $7,14 \pm 0,04^{\mathrm{b}}$ & $1,15 \pm 0,01^{\mathrm{b}}$ & $2,79 \pm 0,03^{\mathrm{b}}$ \\
Asam Sitrat & $6,27 \pm 0,03^{\mathrm{a}}$ & $1,01 \pm 0,01^{\mathrm{a}}$ & $2,89 \pm 0,05^{\mathrm{a}}$ \\
\hline
\end{tabular}

Keterangan: Superskrip berbeda pada kolom yang sama menunjukkan perbedaan nyata $(p<0,05)$.

\section{Komposisi Asam Amino}

Nilai asam amino yang didapatkan dari hasil hidrolisis tiga asam dapat dilihat pada Tabel 4. Nilai asam amino semua perlakuan sedikit lebih rendah apabila dibandingkan dengan pepton komersial, tetapi apabila dibandingkan dari ketiga perlakuan asam, perlakuan terbaik pada perlakuan asam propionat. Nilai asam amino tertinggi pada limbah kepala ikan kurisi dengan hidrolisis asam berbeda didapatkan oleh asam glutamat dengan nilai 4,92 sedangkan untuk pepton komersial didapatkan nilai tertinggi pada glisin sebanyak 16,4. Pepton yang berasal dari hewan seperti sapi, babi dan sebagainya memiliki nilai glisin yang tinggi (Wijayanti, 2009).

Tabel 4. Hasil asam amino fraksi cair.

\begin{tabular}{lllll}
\hline Asam Amino & Difco* & AP & AF & AS \\
\hline Alanin & 7,7 & 2,17 & 0,32 & 0,11 \\
Arginine & 8,6 & 2,90 & 0,39 & 0,05 \\
Aspartic acid & 7,7 & 2,85 & 0,44 & 0,18 \\
Glycine & 16,4 & 3,85 & 0,56 & 0,24 \\
Isoleucine & 1,8 & 1,41 & 0,19 & 0,08 \\
Leucine & 4,4 & 2,67 & 0,36 & 0,13 \\
Glutamic acid & 12,1 & 4,92 & 0,72 & 0,09 \\
Lysne & 4,7 & 2,59 & 0,37 & 0,04 \\
Cystine & 0,2 & n.d & n.d & n.d \\
Methionine & 0,8 & n.d & n.d & n.d \\
Phenylalanine & 2,6 & 1,91 & 0,24 & 0,09 \\
Tyrosine & 0,9 & 1,32 & 0,17 & 0,02
\end{tabular}




\begin{tabular}{lrlll} 
Threonine & 2,5 & 1,77 & 0,24 & 0,03 \\
\multicolumn{2}{l}{ Asam Amino Esensial } & & & \\
Proline & n.d & 1,93 & 0,29 & 0,10 \\
Valine & 2,8 & 1,69 & 0,23 & 0,09 \\
Histidin & 0,8 & 0,97 & 0,12 & 0,02 \\
Serin & 3,9 & 1,59 & 0,23 & 0,08 \\
Taurin & n.d & n.d & n.d & n.d \\
\hline
\end{tabular}

*Shirahigue et al. (2018); $\mathrm{n} . \mathrm{d}=$ not determined.

\section{Optical Density}

Pengukuran OD menggunakan spektrofotometer dengan pengukuran pada waktu inkubasi $E$. coli dan $S$. aureus dengan membandingkan pepton

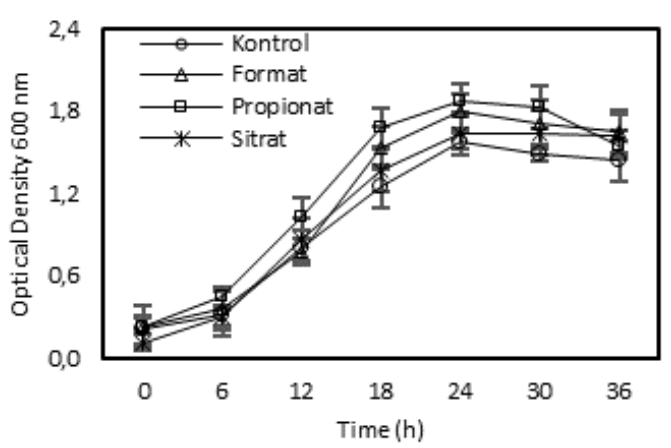

(a) komersial dan pepton hasil ekstraksi limbah kurisi pada jam ke-0 hingga jam ke-36. Performa pertumbuhan $E$. coli dan pertumbuhan $S$. aureus dapat dilihat pada Gambar 2.

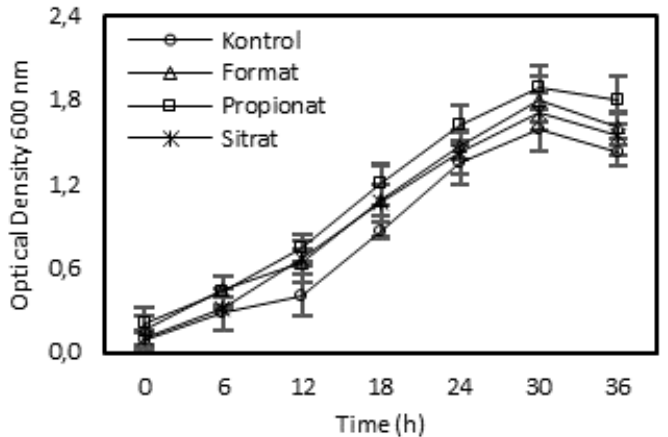

(b)

Gambar 2. Pertumbuhan mikroba berdasarkan OD 600nm (a) E. coli dan(b) S. aureus.

Pertumbuhan tertinggi E.coli dan $S$. aureus didapatkan pada pertumbuhan dengan pepton yang berasal dari hidrolisis asam propionat. Pertumbuhan eksponensial tidak dapat diukur berdasarkan lama waktu, pertambahan jumlah sel bakteri pada media biakan berdasarkan penggunaan nutrien dan produksi hasil sampingan yang dihasilkan (Ingraham et al., 2001). Pepton yang berasal dari hidrolisis limbah ikan mendukung pertumbuhan berbagai mikroorganisme, salah satunya S.aureus berkisar pada 7,00-10,16 log $\mathrm{CFU} / \mathrm{ml}$.
Perbedaan kecepatan maksimum pada media dengan beberapa macam pepton hasil hidrolisis menggunakan asam berbeda diduga disebabkan oleh perbedaan ukuran peptida (Saputra dan Nurhayati, 2013).

\section{Biomassa}

Hasil produksi biomassa bakteri $E$. coli dan $S$. aureus pada pepton komersial dan non komersial hasil ekstraksi menggunakan tiga asam berbeda dengan ditampilkan pada Gambar 3. 

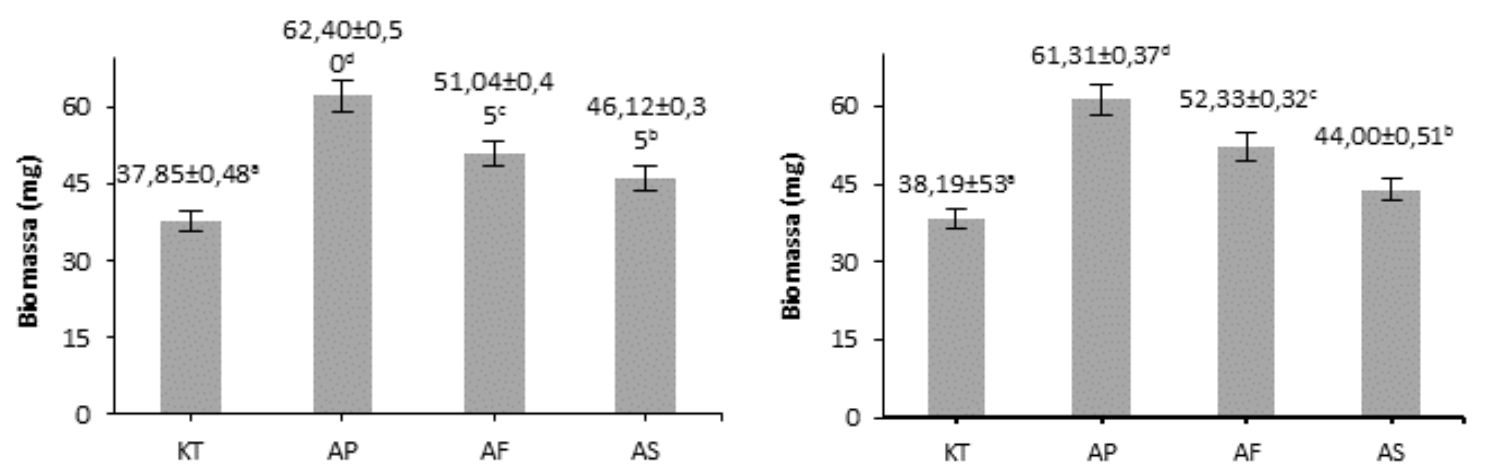

Gambar 3. Produksi biomassa (a) E. coli dan (b) S. aureus. KT: Perlakukan kontrol (pepton komersial), AP: perlakukan asam propionat, AF: perlakuan asam fosfat, AS: perlakuan asam sitrat.

Hasil analisis ANOVA menunjukkan perbedaan jenis asam menghasilkan perbedaan nyata terhadap nilai biomassa $(p<0,05)$. Biomassa tertinggi pada pertumbuhan E. coli dan S. aureus didapatkan pada pepton hasil hidrolisis menggunakan asam propionat yaitu 62,40 $\mathrm{mg}$ dan 54,26 mg. Hasil produksi biomassa pada pepton hasil hidrolisis ikan kurisi mendapat hasil lebih tinggi dibandingkan pepton komersial yaitu $24,96 \mathrm{mg}$ dan $17,33 \mathrm{mg}$.

Hal ini menandakan bahwa pepton yang berasal dari hidrolisis ikan kurisi efektif dalam menumbuhkan media berdasarkan hasil pengujian biomassa yang menandakan bahwa sumber Nitrogen dan Karbon pada pepton untuk pertumbuhan bakteri lebih banyak dan lebih maksimal. Semakin tinggi biomassa yang didapatkan, maka efisiensi penggunaan pepton sebagai substrat pada pertumbuhan mikroba semakin tinggi (Poernomo dan Buckle, 2002).

\section{UCAPAN TERIMA KASIH}

Kami mengucapkan terima kasih kepada semua pihak yang membantu dalam penyelesaian penelitian ini.

\section{KESIMPULAN}

Produksi pepton halal terbaik didapat pada perlakuan asam propionat dengan $\mathrm{pH} 3.6$ rendemen kering 1.7\% nilai total protein $8.12 \%$ Nilai $\mathrm{N}$ total $1.3 \%$ dan protein terlarut $3.68 \mathrm{~g} / \mathrm{L}$, biomassa $E$. coli $62,40 \mathrm{mg}$ dan $S$. aureus $54,26 \mathrm{mg}$ dan hasil performa pertumbuhan bakteri E.coli dan S.aureus dengan OD tertinggi dari semua perlukan termasuk pepton komersial. Temuan ini mengungkapkan bahwa pepton dari limbah ikan kurisi fisibel dikembangkan sebagai produk halal secara komersial untuk media pertumbuhan mikroba. Untuk memproduksi $1 \mathrm{~kg}$ pepton hanya dibutuhkan $70 \mathrm{~kg}$ limbah kepala ikan kurisi yang dihidrolisis menggunakan asam propionat.

\section{DAFTAR PUSTAKA}

Association of Official Analytical Chemists and Association of Official Agricultural Chemists (US), 2005. Official methods of analysis of the Association of Official Analytical Chemists (Vol. 2). Association of Official Analytical Chemists..

Atma, Y., Taufik, M. dan Seftiono, H., 2018. Identifikasi Resiko Titik Kritis Kehalalan Produk Pangan: Studi Produk Bioteknologi. Jurnal Teknologi, 10(1), pp.59-66. 10.24853/jurtek.10.1.59-66

Gildberg, A., Dahl, R., Mikkelsen, H. dan Nilsen, K., 2010. Peptones from Atlantic cod Stomach as nitrogen sources in growth media to marine bacteria. Journal of Aquatic Food Product Technology, 19(2), pp.75- 
83. https://doi.org/10.1080/ 10498850.2010 .486523

Ingraham, J.L., Ingraham, C.A. and Prentiss, H., 2001. Introduction to microbiology: a case-history study approach, 3 ed.,São Paulo: Cengage Learning. Pp. 199.

Nagarajan, M., Benjakul, S., Prodpran, T., Songtipya, P. dan Kishimura, H., 2012. Characteristics and functional properties of gelatin from splendid squid (Loligo formosana) skin as affected by extraction temperatures. Food Hydrocolloids, 29(2), pp.389397. 10.1016/j.foodhyd.2012.04. 001.

Najim, S.M., Al-Noor, J.M. dan Al-Waely, W.A., 2015. Extraction of crude peptone from fish wastes for use as a nitrogen source in microbiological media. Global Journal of Fisheries and Aquaculture Researches, 2, pp.29-37. https://www. researchgate.net/publication/3092 41783_Extraction_of_crude_pepton e_from_fish_wastes_for_use_as_a_n itrogen_source_in_microbiological_ media.

Poernomo, A. dan Buckle, K.A., 2002. Crude peptones from cowtail ray (Trygon sephen) viscera as microbial growth media. World Journal of Microbiology and Biotechnology, 18(4), p.337. https://doi.org/10.1023/A:101520 8519709

Saputra, D. dan Nurhayati, T., 2013. Produksi dan aplikasi pepton ikan selar untuk media pertumbuhan bakteri. Jurnal Pengolahan Hasil Perikanan Indonesia, 16(3), pp.215223. https://doi.org/10.17844/ jphpi.v16i3.8059.

Shirahigue, L.D., Ribeiro, I.S., Sucasas, L.F.D.A., Anbe, L., Vaz-Pires, P. dan Oetterer, M., 2018. Peptones in Silage from Tilapia (Oreochromis niloticus) and Cobia (Rachycentron canadum) Waste as a Culture Medium for Bioprocesses. Journal of aquatic food product technology,
27(6), pp.712-721. https://doi.org/ 10.1080/10498850.2018.1484830.

Trivedi, M.K., Branton, A., Trivedi, D., Nayak, G., Singh, R. dan Jana, S., 2015. Physical, spectroscopic and thermal characterization of biofield treated fish peptone. European Journal of Biophysics, 3(6), pp.5158. 10.11648/j.ejb.20150306.12.

Wijayanti, A.T., 2009. Kajian Penyaringan dan Lama Penyimpanan dalam Pembuatan Fish Peptone dari Ikan Selar Kuning (Caranx leptolepis)[skripsi]. Program Studi Teknologi Hasil Perikanan, Fakultas Perikanan dan Ilmu Kelautan, Institut Pertanian Bogor. Bogor, 88. https://repository.ipb.ac.id/handle /123456789/11463.

Yin, S.W., Tang, C.H., Cao, J.S., Hu, E.K., Wen, Q.B. dan Yang, X.Q., 2008. Effects of limited enzymatic hydrolysis with trypsin on the functional properties of hemp (Cannabis sativa L.) protein isolate. Food chemistry, 106(3), pp.10041013. 10.1016/j.foodchem.2007. 07.030 . 